\title{
Biochemical and cellular characterization of cardiac valve tissue after cryopreservation or antibiotic preservation
}

It has been reported that aortic homografts that have been cryopreserved before transplantation remain viable longer as an allograft than tissue stored at $4^{\circ} \mathrm{C}$ in an antibiotic solution. In the present study, we tested the hypothesis that storage of cardiac valve tissue by cryopreservation or by antibiotic preservation may alter the metabolic status of the tissue. Initially, we collected aortic valves composed of cardiac tissue, aortic root, and valvular tissue from cadaver donors. These specimens were divided into three equal portions, and one portion was analyzed before storage while the other two parts were stored for 3 weeks at either $4^{\circ} \mathrm{C}$ in an antibiotic solution or at $-196^{\circ} \mathrm{C}$ in liquid nitrogen. All specimens were examined with regard to the following parameters: tissue structure, tissue viability, cell proliferative capacity, metabolic function, and identification of cell-specific antigens. We found no significant alterations in the structure of any of the three tissue components after antibiotic preservation or cryopreservation; however, cell viability and cell number were decreased in all three groups. All tissue samples grew in culture before storage. When we compared activities of the following organellar marker enzymes-lysosomal acid lipase, plasma membrane 5' nucleotidase, mitochondrial cytochrome oxidase, and microsomal neutral $\alpha$-glucosidase-we observed no major differences between tissues stored by either technique. In addition, we observed no loss of enzymic activity as a result of storage. Finally, when cell lines isolated from each tissue specimen were incubated with monoclonal antibodies against cell-specific antigens in an immunoperoxidase assay, all the cell cultures proved to be endothelial cells. These results suggest that although cardiac valve tissue stored by cryopreservation or by antibiotic preservation retained its normal structure and metabolic capabilities, both storage techniques produced significant decreases in cell numbers and viability. However, only endothelial cells from tissue stored by cryopreservation retained the capacity to proliferate in vitro. These findings have important implications for the function of aortic homografts transplanted after storage. (J THORAC CaRDIOvaSC SURG 1994;108:63-7)

Samuel J. Lang, DVM, MD, ${ }^{\mathrm{a}}$ Marie S. Giordano, RN, MS, ${ }^{\mathrm{a}}$ Carlos Cardon-Cardo, MD, PhD, ${ }^{\mathrm{b}}$

Barbara D. Summers, BS, ${ }^{c}$ Lisa Staiano-Coico, PhD, ${ }^{a}$ and David P. Hajjar, PhD, ${ }^{\mathrm{c}}$

New York, N.Y.

From the Departments of Biochemistry, ${ }^{\mathrm{c}}$ Pathology, ${ }^{\mathrm{c}}$ and Surgery, ${ }^{\mathrm{a}}$ Cornell University Medical College, and the Department of Pathology, ${ }^{\text {b }}$ Memorial Hospital Sloan-Kettering Institute, New York, N.Y.

Funding was provided by grants from the National Institutes of Health HL-1 8828 and HL-46403.

Received for publication June 28, 1993.

Accepted for publication Nov. 12, 1993.

Address for reprints: David P. Hajjar, PhD, Department of Pathology, Cornell University Medical Center, 1300 York Ave., New York, NY 10021 .

Copyright 1994 by Mosby-Year Book, Inc.

$0022-5223 / 94 \$ 3.00+0 \quad 12 / 1 / 52959$

\begin{abstract}
A llograft aortic valve implantations have been performed clinically for the past two decades with increasing demand. For this reason, the sterilization and preservation methods used to store this tissue have had to be improved. O'Brien and associates reported in a clinical paper comparative data regarding aortic valve replacement with viable, cryopreserved, and freshly isolated allografts valves.' Moreover, it has been reported that aortic allografts that have been cryopreserved before transplantation remain viable longer as an allograft than does tissue stored at $4^{\circ} \mathrm{C}$ in an antibiotic solution. ${ }^{2}$ In the present study, we tested the hypothesis that storage of
\end{abstract}


Table I. Mean levels of marker enzyme activities in cardiovascular tissue

\begin{tabular}{|c|c|c|c|c|}
\hline & $\begin{array}{l}\text { Lysosomes: } \\
\text { ACEH }\end{array}$ & $\begin{array}{c}\text { Mitochondria: } \\
\text { cytochrome oxidase }\end{array}$ & $\begin{array}{c}\text { Microsomes: } \\
\text { neutral glucosidase }\end{array}$ & $\begin{array}{c}\text { Plasma membrane: } \\
\text { 5'-nucleotidase }\end{array}$ \\
\hline \multicolumn{5}{|l|}{ Fresh } \\
\hline Valve & $104 \pm 15$ & $187 \pm 22$ & $31 \pm 3$ & $8333 \pm 887$ \\
\hline Aorta & $86 \pm 16$ & $251 \pm 27$ & $39 \pm 3$ & $7925 \pm 657$ \\
\hline Cardiac & $379 \pm 23$ & $205 \pm 31$ & $26 \pm 3$ & $9830 \pm 971$ \\
\hline \multicolumn{5}{|l|}{ Antibiotic } \\
\hline Valve & $87 \pm 12$ & $161 \pm 10$ & $15 \pm 2$ & $8113 \pm 817$ \\
\hline Aorta & $69 \pm 13$ & $258 \pm 29$ & $27 \pm 3$ & $9827 \pm 932$ \\
\hline Cardiac & $305 \pm 38$ & $208 \pm 40$ & $37 \pm 3$ & $8215 \pm 799$ \\
\hline \multicolumn{5}{|c|}{ Cryopreserved } \\
\hline Valve & $82 \pm 9$ & $215 \pm 33$ & $18 \pm 2$ & $8127 \pm 723$ \\
\hline Aorta & $85 \pm 12$ & $300 \pm 42$ & $41 \pm 3$ & $9326 \pm 1117$ \\
\hline Cardiac & $390 \pm 51$ & $325 \pm 51$ & $28 \pm 3$ & $7964 \pm 821$ \\
\hline
\end{tabular}

Activity per milligram protein as defined in reference 5 . Data are mean \pm standard error of the mean. $\mathrm{N}=3$, where each analysis was done in triplicate. No significant differences existed in marker enzyme activities among the three groups for valve, aorta, or cardiac tissue. $A C E H$, Acid cholesterol ester hydrolase.

Table II. Cell viability and cultivation rates of cardiovascular tissue

\begin{tabular}{llccc}
\hline \multirow{4}{*}{ Treatment } & Tissue & $\begin{array}{c}\text { Viable cells } \\
\left(\times 10^{4}\right)\end{array}$ & $\begin{array}{c}\text { Viability } \\
(\%)\end{array}$ & $\begin{array}{c}\text { Success rate } \\
\text { (mean) }\end{array}$ \\
\hline Fresh & Valve & $1.7^{*} \pm 0.1$ & $48 \dagger \pm 3$ & $3 / 7 \ddagger$ \\
& Aorta & $1.7 \pm 0.2$ & $58 \pm 4$ & $3 / 6$ \\
Antibiotic & Cardiac & $1.2 \pm 0.1$ & $28 \pm 4$ & $2 / 6$ \\
& Valve & $0.9 \pm 0.2$ & $21 \pm 3$ & $0 / 8$ \\
& Aorta & $0.5 \pm 0.1$ & $24 \pm 3$ & $0 / 8$ \\
Cryopreserved & Cardiac & $0.3 \pm 0.1$ & $14 \pm 2$ & $0 / 8$ \\
& Valve & $0.4 \pm 0.1$ & $8 \pm 1$ & $0 / 8$ \\
& Aorta & $0.8 \pm 0.2$ & $24 \pm 3$ & $3 / 7$ \\
& Cardiac & $0.4 \pm 0.1$ & $18 \pm 3$ & $0 / 8$
\end{tabular}

* Mean ( \pm standard error of the mean) number of viable cells after. 12 to 14 days in culture; $n=3$ for each group, where each analysis was done in triplicate.

$\dagger$ Mean ( \pm standard error of the mean) percent viability, assessed by the trypan blue exclusion test after 12 to 14 days in culture; $n=3$ for each group, where each analyses was done in triplicate.

\#Success rate $=$ numbers of tissues that had cells growing in vitro after a 12- to 14-day explant period per total number of tissues in the experiment.

cardiac valve tissue by cryopreservation or by antibiotic preservation may alter the metabolic status of the tissue. Toward this end, we collected aortic valves composed of cardiac tissue, aortic root tissue, and valvular tissue from cadaver donors (Fig. 1). These specimens were divided into three equal portions: one portion was analyzed before storage and the other two parts were stored for 3 weeks at either $4^{\circ} \mathrm{C}$ in an antibiotic solution or at $-196^{\circ} \mathrm{C}$ in liquid nitrogen. All specimens were examined with regard to the following parameters: tissue structure, tissue viability, cell proliferative capacity, metabolic function, and identification of cell-specific antigens.

\section{Experimental procedure}

Collection of donor hearts. Consent for removal of the aorta and heart as an anatomic gift was obtained in accordance with
Table III. Antibody reactivity of cells grown from cardiovascular tissue

\begin{tabular}{lcccccc}
\hline & VIM & MCA & DES & T-138 & F VIII & SI \\
\hline Fresh valve & + & - & - & + & + & - \\
Fresh aorta & + & - & - & + & + & - \\
Fresh cardiac & + & - & - & + & + & - \\
$-196^{\circ}$ C aorta & + & - & - & + & + & - \\
\hline
\end{tabular}

Plus sign (+), Reactivity; minus sign (-), no reactivity; VIM, detects vimentin in cells of mesenchymal origin; $M C A$, muscle common antigen in smooth and skeletal muscle cells; $D E S$, detects desmin in skeletal and smooth muscle cells; $T$ - 138 , detects $25 \mathrm{Kd}$ glycoprotein on endothelial cells; $F$ VIII, detects human factor VIII-related antigen produced by endothelial cells; $S I$, nonrelated isotype (immunoglobulin $G$ ) control serum

New York State Anatomical Gift Laws. Hearts were removed within 9 hours after death. In all cases, donors were kept at morgue-refrigerated temperatures before harvesting of the heart. Donor ages ranged from 24 to 57 years. Causes of death included trauma or myocardial infarctions. The donors had no known diseases, and serologic tests for human immunodeficiency virus (HIV) or hepatitis B virus were negative.

Collection and processing of aortic valves. Aortic valves were dissected aseptically, rinsed in $4^{\circ} \mathrm{C}$ lactated Ringer's solution, and placed in transport medium (RPMI-1640 supplemented with L-glutamine and $10 \%$ fetal bovine serum [FBS]; GibcoBRL Corp.; Grand Island, N.Y.). Each isolated valve was further dissected into its component parts consisting of (1) cardiac muscle, (2) aortic root, and (3) valve leaflet (Fig. 1). Each component (i.e., cardiac muscle, aortic root, or valve leaflet) was then subdivided into three equal parts. The first part was analyzed immediately after harvest by the techniques that are described later. The second portion was stored at $4^{\circ} \mathrm{C}$ for 3 weeks in antibiotic-containing medium that comprised RPMI1640 supplemented with $10 \%$ FBS, gentamicin $(0.05 \mathrm{mg} / \mathrm{ml})$, polymyxin $B(0.01 \mathrm{mg} / \mathrm{ml})$, vancomycin $(0.1 \mathrm{mg} / \mathrm{ml})$, clindamicin $(0.1 \mathrm{mg} / \mathrm{ml})$, and amphotericin $(0.5 \mathrm{mg} / \mathrm{ml})(\mathrm{pH} 7.4$; Gibco). The third portion was placed in antibiotic-containing medium as described earlier. The presence of these antibiotics did not alter cell viability, cell proliferation, or the metabolic status of the tissue. After storage for 12 to 24 hours at $4^{\circ} \mathrm{C}$, the 


\section{COLLECTION OF VALVE}
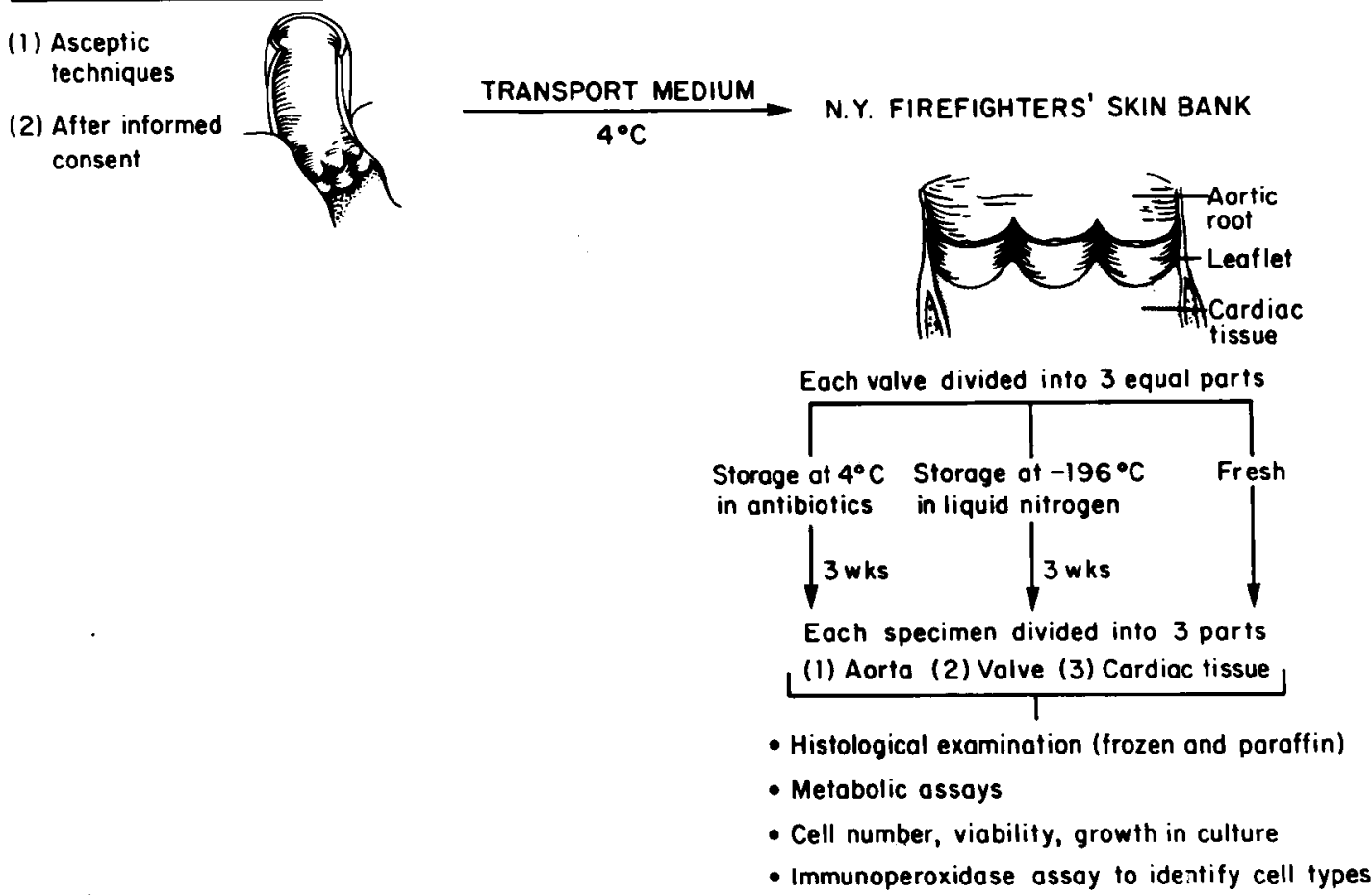

Fig. 1. Overview of asceptic processing of human aortic tissue. Each aorta was dissected into three parts: aortic root, valve leaflet, and cardiac tissue. Each part was then further subdivided into three portions, the first of which was processed immediately, the second of which was stored at $4^{\circ} \mathrm{C}$ for 3 weeks before processing, and the third of which was cryopreserved and stored at $-196^{\circ} \mathrm{C}$ in liquid nitrogen for 3 weeks before processing.

specimens were placed in fresh antibiotic medium supplemented with $10 \%$ dimethyl sulfoxide (DMSO; Fisher Scientific Co., Pittsburgh, $\mathrm{Pa}$.). The specimens were then cryopreserved with a computer-controlled rate freezer that lowered the temperature $1^{\circ} \mathrm{C}$ per minute down to a temperature of $-30^{\circ} \mathrm{C}$, followed by a decrease of $10^{\circ} \mathrm{C}$ per minute to a temperature of $-45^{\circ} \mathrm{C}$. The specimens were then placed in the vapor phase of a liquid nitrogen freezer. After 3 weeks of storage, the specimens were thawed in a $37^{\circ} \mathrm{C}$ shaking water bath, followed by two rinses in prewarmed antibiotic medium.

Analysis of specimens. All specimens (cardiac muscle, aortic root, and valve leaflet) stored under each condition were prepared for (1) histologic examination (frozen and paraffin sections), (2) analysis of the metabolic status of the tissue, (3) cell viability, (4) growth in culture, and (5) immunochemical identification of cell types that grew before and after storage. ${ }^{3}$

Histologic examination. Frozen and paraffin-embedded sections were processed for routine hematoxylin and eosin staining for cell morphology and structural integrity as previously described. ${ }^{4}$

Metabolic status of the tissue specimens. The activities of several marker enzymes representing the major cellular organelles were assayed according to the methods described by Hajjar and colleagues. ${ }^{5}$ These markers included acid cholesteryl ester hydrolase (ACEH), present only in lysosomes; cytochrome oxidase, present only in the mitochondria; neutral glucosidase, present only on microsomes; and 5'-nucleotidase, present only on the plasma membrane. ${ }^{5}$ Assay of these marker enzyme activities are a major index of the metabolic activities in these major organelles of the cell: They reflect the metabolic status of the tissue. ${ }^{5}$

Cell viability and growt he fore and after storage. Single cell suspensions were obtained from all tissue specimens using a cocktail of collagenase and trypsin. Cell viability before and after storage was assessed by trypan blue dye exclusion. ${ }^{6}$ Moreover, the cells that were recovered from each specimen were seeded into culture in RPMI-1640 supplemented with antibiotics and $10 \%$ fetal bovine serum as previously described. ${ }^{6,7}$ Cell growth was then monitored by light microscopy.

Identification of cell types that grew from each tissue specimen. Standard immunoperoxidase assays were performed to identify the cell types that grew out of the pre-storage and poststorage specimens.

Statistical analyses. The mean specific activities of the marker enzymes, mean numbers of viable cells, and the percent viable cells were compared with the use of a single-factor analysis of variance. If the analysis of variance demonstrated significant differences between groups, subsequent pairwise comparison were effected with Duncan's multiple range test.

\section{Results and discussion}

Our results of this study show that the structural integrity of all cardiovascular tissue at the gross level was 

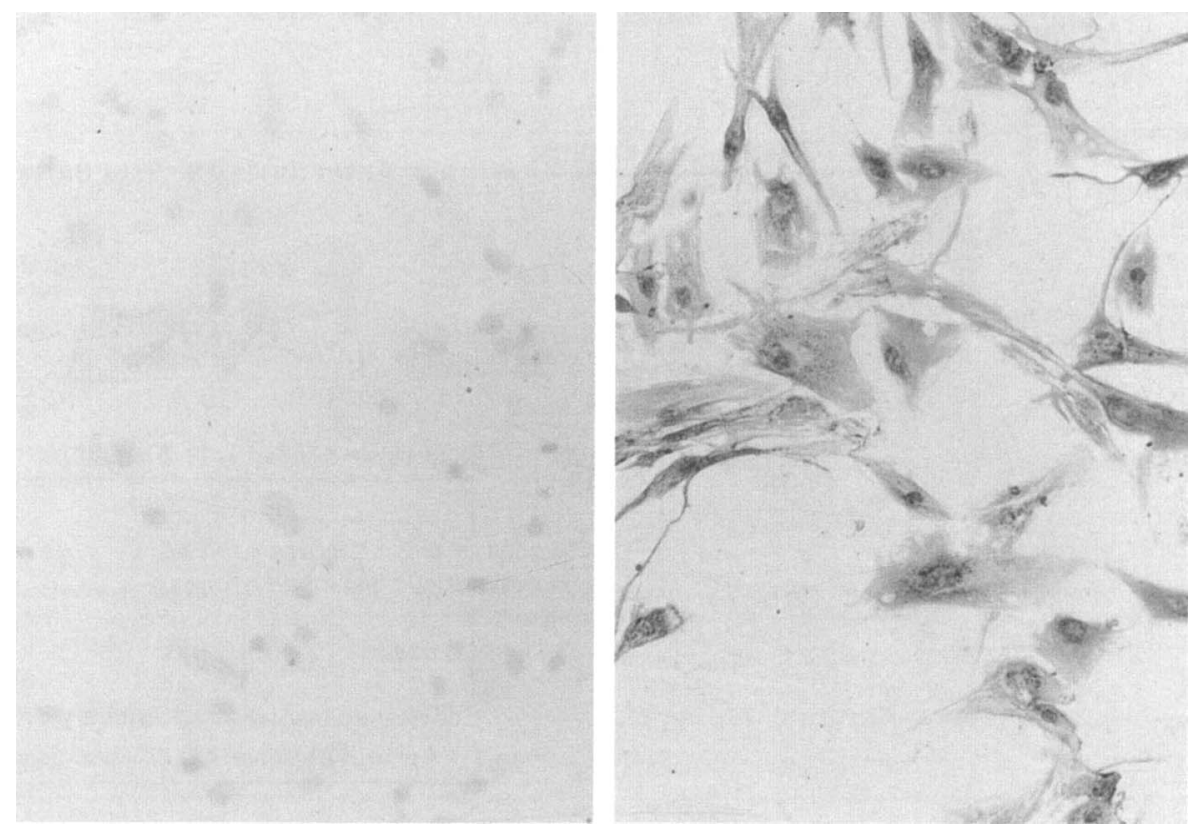

Fig. 2. Identification of cells grown from cardiac tissue. Reaction of cells was assessed with standard immunoperoxidase techniques with an antibody to muscle common antigen (left) or the endothelial cell-specific antibody T-138 (right). Cells grown from cardiac tissue were nonreactive with muscle common antigen but strongly reactive with $\mathrm{T}-138$. These results indicate that the cells grown from cardiac tissue were endothelial in origin.

maintained by either the antibiotic or cryopreservation methods. We also observed that these preservation techniques did not significantly alter the metabolic status of the tissue (Table I), particularly mitochondrial or plasma membrane function in valve, aortic, or cardiac tissue. We interpret these findings to support our hypothesis that preservation of tissue by our procedures will not alter the metabolic capacity of the tissue. However, we did observe that a 3-week exposure to $4^{\circ} \mathrm{C}$ or $-196^{\circ} \mathrm{C}$ caused a decrease in both numbers of viable cells and in the mean percent viability after preservation by other methods (Table II). O'Brien and coworkers' have reported comparative data regarding aortic valve replacement with viable, cryopreserved, and freshly isolated allograft valves. They found that cell viability progressively declines after several days, suggesting degeneration of the tissue. Preparation of tissue for preservation has been shown in other studies to be important in the evaluation of suitability for transplantation. ${ }^{8}$ It has been observed that aortic allografts that have been cryopreserved before transplantation are viable longer as an allograft than tissue stored at $4^{\circ} \mathrm{C}$ in an antibiotic solution.

Histologic evaluation of these tissues showed that they had a normal appearance before and after tissue culture. In particular, there was structural integrity of the tissue such that the matrix appeared preserved with little foci of necrosis in the cells. All three component tissues (aortic root, cardiac muscle, and valve leaflet) grew in culture before antibiotic or cryopreservation. However, only aortic root tissue grew in culture after cryopreservation (Table III); no tissues that were stored at $4^{\circ} \mathrm{C}$ grew in culture. These results at $4^{\circ} \mathrm{C}$ are not surprising, because others have reported that prolonged ( $\geq 3$ weeks) treatment of cardiovascular tissue at $4^{\circ} \mathrm{C}$ will not retard cell necrosis. ${ }^{2,8}$

Finally, all cells grown from components of cardiac valve tissue were identified as endothelial cells on the basis of their appearance in tissue culture ("cobble-stone" cells) and their reactivity with monoclonal antibodies that detect vimentin (found in mesenchymal cells), T-138, which detects a specific $25 \mathrm{Kd}$ glycoprotein only on endothelial cells (Fig. 2), as well as factor VIII antigen (von Willebrand factor) (see Table III). The fact that endothelial cells from tissue stored by cryopreservation retained the capacity to proliferate in vitro may have important implications for the function of aortic homografts transplanted after storage. Because endothelial cells express class II antigens and fibroblasts do not, we believe that these findings are important when implanting aortic homografts into nonrelated recipients.

In summary, the major findings of this study show the following: (1) Preservation of cardiovascular tissue by the 
with viable cryopreserved and fresh allograft valves, with a note on chromosomal studies. $\mathbf{J}$ THORAC CARDIOvasC SURG 1987;94:812-23.

2. O'Brien MF, Stafford G, Gardner M, et al. The viable cryopreserved allograft aortic valve. J Card Surg 1987;2(Suppl 1):153-67.

3. Jaffe EA, ed. Biology of endothelial cells. Boston: Martinus Nijhoff, 1984.

4. Gavin JB, Barratt-Boyes BG, Hitchcock GC, Herdson PB. Histopathology of "fresh" human aortic valve allografts. Thorax 1973;28:482-7.

5. Hajjar DP, Falcone DJ, Fowler S, Minick CR. Endothelium modifies altered metabolism of the injured aortic wall. Am J Pathol 1981;102:28-39.

6. Hajjar DP, Weksler BB, Falcone DJ, Goldman K, Minick CR. Prostacyclin modulates cholesteryl ester metabolism by its effect on cyclic AMP in aortic smooth muscle cells. J Clin Invest 1982;70:479-88.

7. Hajjar DP, Falcone DJ, Amberson JB, Hefton JM. Interaction of vascular cells. J Lipid Res 1985;26:1212-23.

8. Khanna SK, Ross JK, Monro JL. Homograft aortic valve replacement; seven years' experience with antibiotic-treated valves. Thorax 1981;36:330-7. define biologic factors involved in sustaining cell viability preservation procedures to enhance maximum viability for transplantation are still necessary for long-term clinfor transplantation are still necessary for long-term clin-
ical adaptation.

\section{REFERENCES}

antibiotic or cryopreservation methods did not alter the metabolic status of the tissue that continued smooth muscle cells, endothelial cells, and some macrophages; (2)
the numbers of viable cells from all three tissue groups (valve, aorta, cardiac) declined after preservation by either method; (3) all three tissue groups had cells growfrom aortic tissue grew in culture after cryopreservation and no tissue sustained cell growth if it was stored at $4^{\circ}$ $C$, and (4) the cells that successfully grew from the tissue identified as endothelial cells.

These findings reported herein encourage us to further and growth after tissue storage because refinements in

\footnotetext{
1. O'Brien MF, Stafford EG, Gardner MAH, Pohlner PG,
McGriffin DC. A comparison of aortic valve replacement

1. O'Brien MF, Stafford EG, Gardner MAH, Pohlner PG,
McGriffin DC. A comparison of aortic valve replacement
} 